University of Nebraska - Lincoln

DigitalCommons@University of Nebraska - Lincoln

Faculty Publications, Department of Psychology

Psychology, Department of

2002

\title{
Antisocial Alcoholism and Serotonin-Related Polymorphisms: Association Tests
}

\author{
Elizabeth M. Hill \\ University of Detroit Mercy, hillelm@udmercy.edu \\ Scott F. Stoltenberg \\ University of Nebraska-Lincoln, sstoltenberg2@unl.edu \\ Katherine Harris Bullard \\ University of Michigan, Ann Arbor \\ Sheng Li \\ University of Michigan, Ann Arbor \\ Robert A. Zucker \\ University of Michigan, Ann Arbor \\ See next page for additional authors
}

Follow this and additional works at: https://digitalcommons.unl.edu/psychfacpub

Part of the Psychiatry and Psychology Commons

Hill, Elizabeth M.; Stoltenberg, Scott F.; Bullard, Katherine Harris; Li, Sheng; Zucker, Robert A.; and Burmeister, Marget, "Antisocial Alcoholism and Serotonin-Related Polymorphisms: Association Tests" (2002). Faculty Publications, Department of Psychology. 497.

https://digitalcommons.unl.edu/psychfacpub/497

This Article is brought to you for free and open access by the Psychology, Department of at DigitalCommons@University of Nebraska - Lincoln. It has been accepted for inclusion in Faculty Publications, Department of Psychology by an authorized administrator of DigitalCommons@University of Nebraska - Lincoln. 


\section{Authors}

Elizabeth M. Hill, Scott F. Stoltenberg, Katherine Harris Bullard, Sheng Li, Robert A. Zucker, and Marget Burmeister 


\title{
Antisocial Alcoholism and Serotonin-Related Polymorphisms: Association Tests
}

\author{
Elizabeth M. Hill, ${ }^{1,2}$ Scott F. Stoltenberg, ${ }^{2}$ Katherine Harris Bullard, ${ }^{2}$ Sheng $L i,{ }^{3}$ \\ Robert A. Zucker, ${ }^{2}$ and Marget Burmeister ${ }^{3,4}$ \\ 1. Department of Psychology, University of Detroit Mercy, Detroit, Michigan, USA; \\ 2. Department of Psychiatry and Addiction Research Center, University of Michigan, Ann Arbor, Michigan, USA \\ 3. Mental Health Research Institute, University of Michigan, Ann Arbor, Michigan, USA \\ 4. Department of Human Genetics, University of Michigan, Ann Arbor, Michigan, USA
}

Corresponding author - Elizabeth M. Hill, PhD, Associate Professor, Department of Psychology, University of Detroit Mercy, 8200 West Outer Drive, Detroit, MI 48219, USA. Email hillelm@udmercy.edu

\begin{abstract}
Central serotonin dysfunction appears to be related to a subtype of alcoholism with antisocial impulsive features (type II; antisocial alcoholism). The serotonergic deficit may be associated with greater impulsivity, which in turn facilitates both alcohol dependence and antisocial behavior. The present study tested association of antisocial impulsive alcoholism with candidate genes related to serotonergic neurotransmission, using families. Eight markers were assayed using polymerase chain reaction: tryptophan hydroxylase (intron 7), the serotonin transporter SLC6A4 (VNTR 9/12), HTTLPR, the three serotonin receptor types HTR1B (G861C), HTR2A (T102C) and HTR2C (Cys23Ser), monoamine oxidase A (T1460C), and (CA). Eligible probands had early age of onset of alcoholism, child conduct disorder, and two or more symptoms of adult Antisocial Personality Disorder. This sample included 35 probands, their parents, and some siblings $(n=116)$. Association tests were conducted using the Haplotype Relative Risk method for antisocial alcoholism diagnosis and the George-Elston regression method (the S.A.G.E. program ASSOC) for quantitative antisocial alcoholism severity. Haplotype Relative Risk analyses were not significant at the 0.05 level for any of the markers. Trends suggestive for future research occurred for tryptophan hydroxylase and HTR2A. Quantitative ASSOC analyses showed significant marker effects $(P<0.05)$ for both monoamine oxidase A markers, which were in linkage disequilibrium. Antisocial alcoholism symptom severity was higher with monoamine oxidase A C homozygotes or hemizygotes, indicating that low monoamine oxidase activity may be important. Future studies are needed to examine joint and interactive effects of serotonin-related markers.
\end{abstract}

Keywords: alcoholism, genetic association, serotonin, antisocial personality disorder, impulsivity, monoamine oxidase

\section{Introduction}

Linkage and association studies have been used to uncover the genetic basis of vulnerability to alcoholism. Two major long-term efforts of broad scope have used linkage analysis. The Collaborative Study on the Genetics of Alcoholism (Reich et al., 1998) has focused on segregation and linkage analyses of a large sample of alcoholism-dense families ascertained from probands in treatment. A complementary effort at the NIAAA Neurogenetics Laboratory (Long et al., 1998) used genetically isolated populations to study association and linkage. Both genome-wide linkage analyses found a protective effect against alcohol dependence of the region on chromosome 4 containing genes related to alcohol metabolism, alcohol dehydrogenase and aldehyde dehydrogenase (Long et al., 1998; Reich et al., 1998). Faster metabolism of alcohol to acetaldehyde lowers tolerance by causing aversive flushing (Chen et al., 1996). In addition, significant locations on chromosomes 1 and 7 were found in the original Collaborative Study on the Genetics of Alcoholism sample (Reich et al., 1998), which has been replicated in additional families (Foroud et al., 2000). In contrast, a site on chromosome 11 showed linkage in the NIAAA Neurogenetics Laboratory study of a Native American sample (Long et al., 1998).

With the exception of the alcohol dehydrogenase/aldehyde dehydrogenase cluster (Thomasson et al., 1993; Whitfield, 1994; Chen et al., 1996), association studies with alcoholism have not been consistent. Alcoholism, broadly defined, is likely to be a complex trait (Lander and Schork, 1994), characterized by incomplete pene- 
trance, phenocopies, heterogeneity, or polygenic inheritance; genes, the environment, and their interactions play roles in the etiology of alcoholism. One approach to simplify such complexity is to refine the definition of a disease or to isolate homogeneous subgroups more likely to show Mendelian inheritance (Lander and Schork, 1994; McGuffin et al., 1994). Criteria that have been useful are age at onset, family history, severity, and clinical phenotype. Antisocial alcoholism (AAL) is characterized by early age of onset, dense family history of alcoholism, and antisocial characteristics (Cloninger et al., 1981; Cloninger, 1987; Zucker, 1987; Zucker et al., 1996). The AAL subtype appears to be more transmissible than broadly defined alcohol dependence, with a twofold or threefold greater risk of alcoholism in firstdegree relatives (Reich and Cloninger, 1990; McGue, 1994), and relative risks for sons of AAL fathers of 6.9 to develop AAL (reviewed in Cloninger, 1987). Thus, AAL is a promising subtype for genetic analysis because of its early age at onset, dense family history, and restricted phenotype.

Association studies at present require the identification of a few variants in a small number of genes. Ideally, association studies use functional candidate gene markers with demonstrable biological relevance to the specific disorder. Evidence is accumulating that AAL is associated with low serotonin activity (first proposed by Ballenger et al., 1979; see also LeMarquand et al., 1994). Virkkunen and Linnoila (1993) presented a model of serotonin effects on drinking, in which they specified a relationship between serotonin and impulsivity, which may lead to drinking, which in turn releases previously inhibited aggression. Similarly, McGue (1994) proposed behavioral under control as the hallmark characteristic underlying AAL. Thus, serotonin-related makers are plausible candidate genes for an AAL phenotype (reviewed in Hill et al., 1999).

The rate-limiting enzyme in the biosynthesis of serotonin is tryptophan hydroxylase. A family study (sibpairs) of an intronic variant found linkage with broadly defined alcoholism but not for an AAL subgroup (Nielsen et al., 1998). Several genes related to serotonin (5-HT) receptors have also been tested in association studies. An association of a silent variant in the gene for the receptor $5-\mathrm{HT}_{1 \mathrm{~B}} / 5-\mathrm{HT}_{1 \mathrm{D} \beta}(\mathrm{HTR} 1 \mathrm{~B})$ was reported in a Finnish AAL sibpair sample, whereas no linkage was shown in a sample of southwestern Native American sibpairs (Lappalainen et al., 1998). Other negative association studies include case-control studies of nonAAL and variants in the genes for the $5-\mathrm{HT}_{2 \mathrm{~A}}$ receptor and a coding variant of 5- $\mathrm{HT}_{2 \mathrm{C}}$ (HTR2C) (Schuckit et al., 1999; Himei et al., 2000; Parsian and Cloninger, 2001). Parsian and Cloninger (2001) reported an association between HTR2A and alcoholism, broadly defined. Lappalainen et al. (1999) found no linkage in a sibpair design between HTR2C and an AAL phenotype in a group of Finnish violent offenders.

Several studies have investigated association between markers for serotonin re-uptake. Results for a functional promoter variant (HTTLPR) in the serotonin transporter gene (SLC6A4) have been mixed. Among Finnish male alcoholics (Hallikainen et al., 1999), the S allele was more frequent for the AAL subtype compared with controls, and similar results were reported for German AAL subjects (Sander et al., 1998). In a study of antisocial alcoholics in Japan, where the L allele is generally less frequent (Gelernter et al., 1999), however, the L allele was more frequent in AAL subjects than among controls (Ishiguro et al., 1999). Hammoumi et al. (1999) tested three different polymorphisms in the SLC6A4 gene in male and female Caucasians of French origin: the HTTLPR, a VNTR polymorphism, and a restriction fragment length polymorphism. The HTTLPR S-allele showed a significant association with broadly defined alcohol dependence, and a trend for association of a VNTR polymorphism based on numbers of repeats. However, Schuckit et al. (1999) reported a significant, opposite association of alcohol dependence diagnosis and the HTTLPR genotype in Caucasian males. Parsian and Cloninger (2001) also reported a higher frequency of the $\mathrm{L}$ allele for an AAL subgroup, compared with a normal control group. In the only family study of HTTLPR, Edenberg et al. (1998) found no association with alcohol dependence. This large study had ample power to uncover such an association if it existed.

Markers of monoamine oxidase (MAO) activity (5HT catabolism) have also been of great interest, due to previous studies of reduced platelet MAO activity among alcoholics with early onset or other AAL features (von Knorring et al., 1985; Tabakoff et al., 1988; Sherif et al., 1992). In addition, a null mutation in the MAOA gene leads to impulsive aggressive outbursts in affected males of a single extended family (Brunner, 1993). Affected family members did not show alcoholism, however. Case-control studies with the AAL subtype have examined four MAOA markers: T1460C (EcoRV), Fnu4HI, a (CA) repeat, and a VNTR polymorphism. Although there is some disagreement, overall there is significant evidence for association of MAOA with AAL. Parsian (1999) found both the T1460C and Fnu markers significantly associated with AAL, but not the CA repeat (see also Parsian and Cloninger, 2001). For an AAL subtype, Parsian (1999) verified case-control differences in haplotypes of MAOA by testing a small sam- 
ple of mothers by the transmission disequilibrium test. Gade et al. (1998) found one VNTR allele to be higher for substance abuse patients, compared with alcohol-dependent patients. In addition, a functional 30 base pair repeat polymorphism in the promoter of MAOA was recently reported to be associated with AAL (Samochowiec et al., 1999).

Although these studies had widely differing criteria for subtyping, they all fall within the spirit of AAL as a phenotype involving the presence of early onset alcohol problems and antisocial traits. Most evidence for these associations derives from case-control rather than family-based studies. The present study tests associations of antisocial-impulsive alcoholism (AAL) with candidate genes related to serotonergic neurotransmission, using a family-based association design. Men and women with both alcohol dependence and antisocial traits were recruited. While alcoholism is certainly a complex phenotype, we expected that single gene effects could be detected when using a homogeneous subtype to reduce heterogeneity (cf. Lander and Schork, 1994).

\section{Methods}

\section{Recruitment}

Families were recruited through probands from treatment settings (21/35) and community sources (16/35; i.e., posted notices and advertisements). Eligible probands had early age of onset of alcoholism ( $<25$ years), child conduct disorder, and two or more symptoms of adult antisocial personality disorder, using the Diagnostic Interview Schedule (DIS-III-R; Robins et al., 1981). Other comorbid disorders were not exclusionary, except for schizophrenia and bipolar disorder. Parental psychopathology was not exclusionary, except that both parents could not have a history of alcoholism. This sample included 35 probands and their families, most involving both biological parents $(n=32)$, and the final three instead involving a mother and a sibling. Additional siblings were included if feasible, along with two sole probands, resulting in 116 total participants for quantitative analysis (66 male, 50 female; 108 Caucasian, five Hispanic, three African- American). Proband-parent trios $(n=35)$ were used for Haplotype Relative Risk (HRR) analyses.

\section{Measures}

\section{DNA analysis}

Genomic DNA was extracted from leucocytes $(n=110)$ or buccal cells $(n=6)$ using the PUREGENE Kit (Gen- tra Systems, Minneapolis, Minnesota, USA). Table 1 describes the polymorphisms for the markers tested, showing the restriction enzyme employed and the size of the resulting fragments. Polymerase chain reaction conditions (e.g., primer sequences and restriction enzymes) for markers were also taken from the respective articles presented in Table 1 . In some cases, minor modifications were made to protocols to optimize yield. For specific Polymerase chain reaction conditions used for each marker, see http://www-personal.umich. edu/ sstolten/Work/Hill_PCR_Methods.htm .

\section{Clinical measures}

All probands were assessed using the DIS-III-R (Robins et al., 1981). Other assessments for the proband focused on features of AAL, specifically impulsivity and aggression. The Antisocial Behavior Checklist (Zucker et al., 1994) was also used to measure specific antisocial symptoms. The Family History Assessment Module (Rice et al., 1995) was used to collect information from the proband on alcoholism, antisocial behavior, and substance abuse by first-degree relatives. Personal diagnostic interviews were conducted with all probands and with the first 24 sets of parents. Subsequently, a brief interview was instituted for the remaining 11 sets of parents. Analyses reported in the present paper involved the DIS-III-R measures of alcoholism and antisocial personality. Quantitative analyses used a summary variable to capture AAL severity along a continuum, referred to as AALSEV, calculated as the sum of DIS symptoms of both alcoholism and antisocial personality disorder (ALC3RSX + ASP3RSX). This quantitative measure parallels the diagnosis of AAL, as used in proband recruitment. If an individual had no symptoms of alcoholism or no symptoms of antisocial personality, the AALSEV measure was set to zero (0), to be consistent with the conception of AAL as a disorder requiring both problems. Thus, persons without both types of problems had severity of zero. The maximum scores resulted from having high levels of symptoms in both disorders. In fact, ASP3RSX has somewhat more weight in the AALSEV total, since the maximum number is 16 symptoms, while the ALC3RSX maximum is nine symptoms. AALSEV scores were not available from the DIS for 19 parents, because they did not have personal diagnostic interviews. In 14 cases, family history interview information was available from the Family History Assessment Module and was used to impute a quantitative score for AALSEV. 


\section{Results}

\section{Participants}

Table 2 describes the demographic and clinical characteristics of the participants (probands and parents). Probands (26 men, 11 women; 35/37 Caucasian) had young alcoholism onset (mean, $14.91 \pm 3.53$ years), and numerous symptoms of alcohol dependence and antisocial personality disorder. The nine siblings (five men, four women) used in the quantitative ASSOC analyses are not shown in Table 2; none were positive for antisocial personality disorder. Seven were alcohol dependent. All probands met criteria for childhood conduct disorder. The most frequent problem behaviors occurring during childhood ( $\leq 15$ years old) were "trouble with teachers" (71.4\%), "lying" (71.4\%), "truancy" (71.4\%), and "stealing" (67.9\%). Least often endorsed were "using weapons" (7.1\%) and "firesetting" (28.6\%). Most frequent adult ( $>15$ years old) problems were "driving offenses" (96.4\%), "being in debt" (82.1\%), "criminal activity" (67.9\%), and "arrests" (67.9\%). Least common adult problems were "using aliases" (14.3\%) and "firesetting" $(14.3 \%)$.
Linkage disequilibrium

Significant linkage disequilibrium is evident between the two MAOA markers (male probands, $\chi_{5}^{2}=15.23, P=$ 0.009; fathers, $\chi_{5}^{2}=23.36, P=0.001$ ). Table 3 presents the allele distribution. The MAOAC allele was usually present when the CA repeat was $\leq 115$.

\section{HRR results}

Table 4 presents the HRR results. For parental alleles, the table lists the proportion of each allele type that was transmitted to the proband. Using HTR2A as an example, 44 of the 78 parental $\mathrm{C}$ alleles were transmitted (56\%), compared with $20 / 50(40 \%)$ of the T alleles. Chisquare tests were not significant at the $P<0.05$ level for any of these markers (Table 4). A trend suggestive for future research occurred for tryptophan hydroxylase, with a slight excess of transmitted $U$ alleles (transmitted, 38/66 U, 26/62 L; $x^{2}=3.058, P=0.076$ ). While not statistically significant, HTR2A showed a slight excess of transmitted C alleles (transmitted, 20/50 T, 44/78 C; $\chi^{2}=3.299, P=0.069$ ).

Table 2. Demographic and clinical characteristics of participants

\begin{tabular}{lcc}
\hline Measure & \multicolumn{2}{c}{ Probands } \\
\cline { 2 - 3 } & Men $(n=26)$ & Women $(n=11)$ \\
\hline Age (years) & $31.0 \pm 8.2$ & $33.9 \pm 6.5$ \\
Years education & $13.3 \pm 2.2$ & $14.2 \pm 1.9$ \\
Lifetime diagnoses & $100.0 \%$ & $100.0 \%$ \\
Alcohol dependence & $84.6 \%$ & $44.0 \%$ \\
Antisocial personality disorder & $56.0 \%$ & $77.8 \%$ \\
Depression & $88.0 \%$ & $82.0 \%$ \\
Drug abuse/dependence & & \\
Symptom counts & $8.1 \pm 1.4$ & $8.4 \pm 1.2$ \\
Alcoholism symptom count & $8.8 \pm 3.7$ & $7.5 \pm 4.4$ \\
Antisocial symptom count & $16.8 \pm 4.2$ & $16.0 \pm 4.4$ \\
Antisocial alcoholism severity & \multicolumn{2}{c}{ Parents } \\
\cline { 2 - 3 } & Fathers $(n=32)$ & Mothers $(n=35)$ \\
\hline Age (years) & $60.9 \pm 8.6$ & $58.7 \pm 10.2$ \\
Years education & $14.0 \pm 1.9$ & $13.9 \pm 1.9$ \\
Lifetime diagnoses & \multicolumn{2}{c}{$13.1 \%$} \\
Alcohol dependence & $58.3 \%$ & $00.0 \%$ \\
Antisocial personality disorder & $8.3 \%$ & $30.4 \%$ \\
Depression & $12.5 \%$ & $8.7 \%$ \\
Drug abuse/dependence & $17.7 \%$ & $0.7 \pm 2.0$ \\
Symptom counts & $3.6 \pm 3.0$ & $0.7 \pm 1.9$ \\
Alcoholism symptom count & $2.5 \pm 3.2$ & \\
Antisocial symptom count & $5.3 \pm 5.9$ & \\
Antisocial alcoholism severity & \multicolumn{2}{c}{} \\
\hline
\end{tabular}


Table 3. Linkage disequilibrium between MAOAT1460C and $(\mathrm{CA})_{n}$ markers

\begin{tabular}{|c|c|c|c|c|c|c|c|c|}
\hline \multirow[t]{2}{*}{ T1460C } & \multicolumn{8}{|c|}{$\mathrm{CA}$} \\
\hline & 111 & 113 & 115 & 117 & 121 & 123 & 125 & 127 \\
\hline \multicolumn{9}{|c|}{ Probands } \\
\hline C & 1 & 12 & 2 & 0 & 1 & 0 & 0 & 0 \\
\hline $\mathrm{T}$ & 0 & 2 & 0 & 0 & 5 & 1 & 2 & 0 \\
\hline Total & 1 & 14 & 2 & 0 & 6 & 1 & 2 & 0 \\
\hline \multicolumn{9}{|l|}{ Fathers } \\
\hline C & 2 & 13 & 4 & 0 & 0 & 0 & 0 & 0 \\
\hline $\mathrm{T}$ & 0 & 2 & 0 & 1 & 8 & 1 & 0 & 1 \\
\hline Total & 2 & 15 & 4 & 1 & 8 & 0 & 0 & 1 \\
\hline
\end{tabular}

Quantitative ASSOC results

Quantitative ASSOC analyses showed a significant marker effect for both MAOA markers (Table 5). Mean symptom levels are presented in Table 5 for probands and for the entire sample. Proband levels of AALSEV were generally high regardless of genotype, whereas more variation was shown when examining the full sample. AALSEV appeared higher with MAOA C/0 or $\mathrm{C} / \mathrm{C}$ and MAOACA $\leq 115$ (L). AALSEV levels appeared to be higher for those with the MAOAC allele. Symptom levels showed a similar pattern for MAOACA.

Table 4. Haplotype Relative Risk association analysis results $\left(X^{2}\right)$

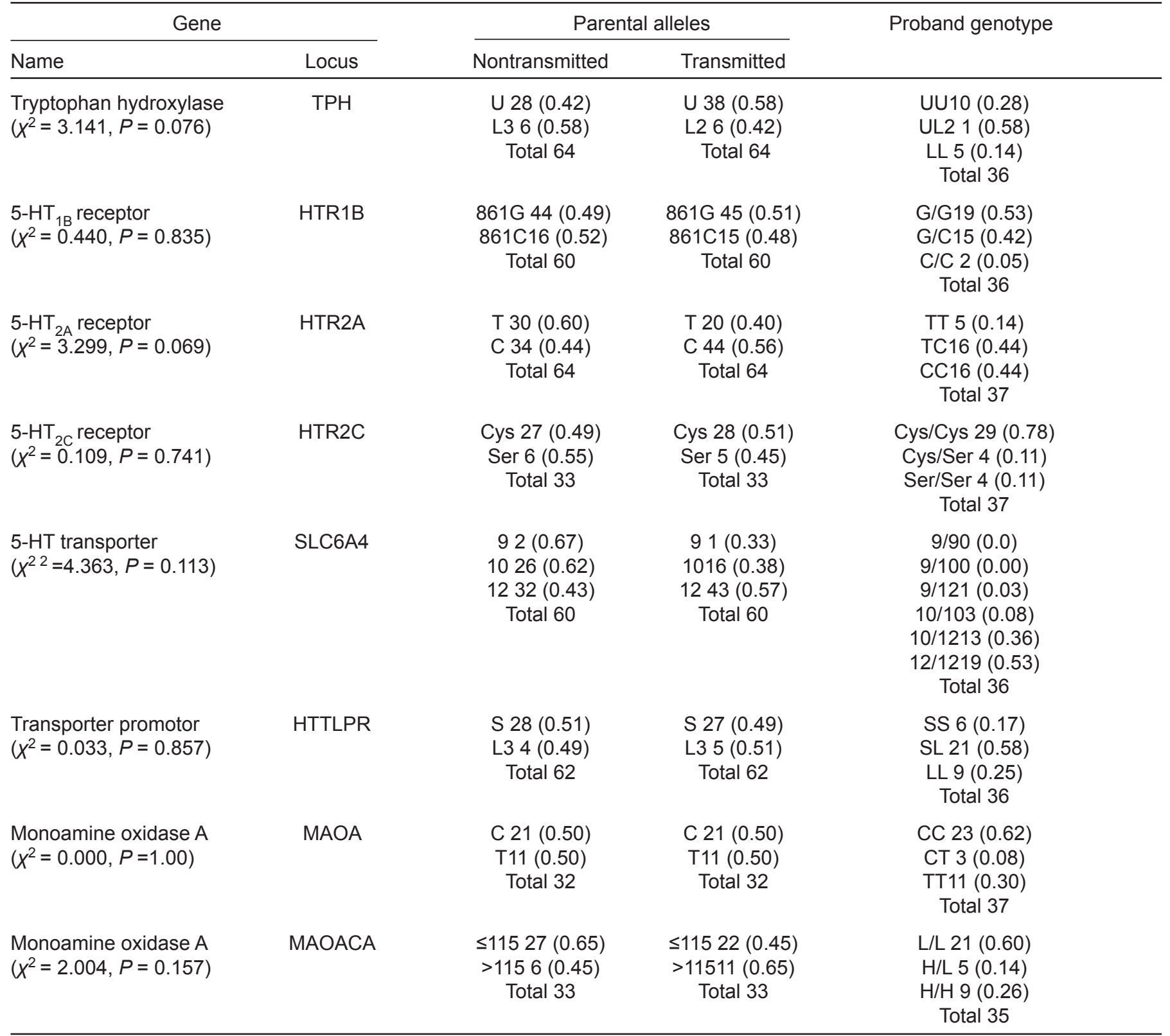

Number and proportion of alleles transmitted from parents to probands are shown. The distribution of genotypes for probands is also shown. 
Table 5. Relationship of genotype to severity: numberof symptoms of antisocial alcoholism (AALSEV)

\begin{tabular}{|c|c|c|c|c|c|}
\hline \multicolumn{2}{|c|}{ Gene } & \multicolumn{2}{|c|}{ Probands } & \multicolumn{2}{|c|}{ All individuals } \\
\hline $\begin{array}{l}\text { Tryptophan hydroxylase } \\
\left(x^{2}=2.690, P=0.101\right)\end{array}$ & $\mathrm{TPH}$ & $\begin{array}{l}\text { UU10 } \\
\text { UL21 } \\
\text { LL5 }\end{array}$ & $\begin{array}{l}17.20 \\
16.71 \\
15.80\end{array}$ & $\begin{array}{l}\text { UU } 23 \\
\text { UL65 } \\
\text { LL17 }\end{array}$ & $\begin{array}{r}10.04 \\
7.91 \\
5.11\end{array}$ \\
\hline $\begin{array}{l}5-\mathrm{HT}_{1 \mathrm{~B}} \text { receptor } \\
\left(X^{2}=1.228, P=0.268\right)\end{array}$ & HTR1B & $\begin{array}{l}861 \mathrm{G} / \mathrm{G} 19 \\
861 \mathrm{G} / \mathrm{C} 15 \\
861 \mathrm{C} / \mathrm{C} 2\end{array}$ & $\begin{array}{l}16.94 \\
16.87 \\
13.50\end{array}$ & $\begin{array}{l}861 \mathrm{G} / \mathrm{G} 54 \\
861 \mathrm{G} / \mathrm{C} 43 \\
861 \mathrm{C} / \mathrm{C} 7\end{array}$ & $\begin{array}{l}8.74 \\
7.44 \\
5.71\end{array}$ \\
\hline $\begin{array}{l}5-\mathrm{HT}_{2 \mathrm{~A}} \text { receptor } \\
\left(x^{2}=0.102, P=0.749\right)\end{array}$ & HTR2A & $\begin{array}{l}\text { TT } 5 \\
\text { TC16 } \\
\text { CC16 }\end{array}$ & $\begin{array}{l}15.20 \\
16.63 \\
17.00\end{array}$ & $\begin{array}{l}\text { TT19 } \\
\text { TC } 43 \\
\text { CC } 45\end{array}$ & $\begin{array}{l}7.47 \\
8.44 \\
7.53\end{array}$ \\
\hline $\begin{array}{l}5-\mathrm{HT}_{2 \mathrm{C}} \text { receptor } \\
\left(X^{2}=0.132, P=0.716\right)\end{array}$ & $\begin{array}{l}\text { HTR2C } \\
\text { Men } \\
\text { Women }\end{array}$ & $\begin{array}{l}\text { Cys } 22 \\
\text { Ser } 4 \\
\text { Cys/Cys } 7 \\
\text { Cys/Ser } 4 \\
\text { Ser/Ser } 0\end{array}$ & $\begin{array}{l}16.73 \\
17.50 \\
15.43 \\
17.00 \\
-\end{array}$ & $\begin{array}{l}\text { Cys } 53 \\
\text { Ser } 7 \\
\text { Cys/Cys } 32 \\
\text { Cys/Ser14 } \\
\text { Ser/Ser1 }\end{array}$ & $\begin{array}{r}9.74 \\
16.43 \\
4.09 \\
5.86 \\
0.00\end{array}$ \\
\hline $\begin{array}{l}5-\mathrm{HT} \text { transporter } \\
\left(X^{2}=1.962, P=0.161\right)\end{array}$ & SLC6A4 & $\begin{array}{l}9 / 90 \\
9 / 100 \\
9 / 121 \\
10 / 103 \\
10 / 1212 \\
12 / 1219\end{array}$ & $\begin{array}{l}- \\
- \\
22.00 \\
17.00 \\
16.08 \\
16.79\end{array}$ & $\begin{array}{l}9 / 90 \\
9 / 101 \\
9 / 124 \\
10 / 1013 \\
10 / 1238 \\
12 / 1247\end{array}$ & $\begin{array}{l}- \\
0.00 \\
8.75 \\
6.69 \\
6.55 \\
9.45\end{array}$ \\
\hline $\begin{array}{l}\text { Transporter promoter } \\
\left(X^{2}=1.199, P=0.273\right)\end{array}$ & HTTLPR & $\begin{array}{l}\text { SS } 6 \\
\text { SL2 } 1 \\
\text { LL } 9\end{array}$ & $\begin{array}{l}18.00 \\
16.19 \\
17.11\end{array}$ & $\begin{array}{l}\text { SS19 } \\
\text { SL5 } 5 \\
\text { LL } 31\end{array}$ & $\begin{array}{l}6.79 \\
8.51 \\
7.58\end{array}$ \\
\hline
\end{tabular}

Quantitative association results for all individuals (ASSOC $x^{2}$ ) are given under each marker name. Mean and $n$ values are presented.

Parental subsample

The samples of fathers and mothers constitute groups of independent individuals with a broad range of alcohol and antisocial symptoms. About one-half of the fathers were alcohol dependent. All but one of these had age of onset prior to age 25 years, and a subset of these $(n=13)$ had two or more symptoms of antisocial personality disorder. Only three mothers had alcohol abuse or dependence, but there was variation in AALSEV symptom count. The pattern shown by the parental subgroup was examined to determine whether it was consistent with the findings from the analyses for the entire group of families, which suggested association of AAL with MAOA markers. Analysis of variance was used to test differences in AALSEV ( $\log _{\mathrm{e}}$ transformed) by genotype. Heterozygote C/T women were pooled with the homozygote $\mathrm{T} / \mathrm{T}$ group, and men and women were analyzed together. Higher AALSEV levels were shown by those with the $\mathrm{C}$ allele [fathers: $\mathrm{C} / 0(n=17), 6.47 \pm 6.81$; $\mathrm{T} / 0(n$ $=13), 3.85 \pm 4.08$; mothers: $\mathrm{C} / \mathrm{C}(n=12), 2.80 \pm 4.43 ; \mathrm{C} / \mathrm{T}$ $(n=16), 0.81 \pm 3.25 ; \mathrm{T} / \mathrm{T}(n=3), 0.0 \pm 0.0)$. The effect of genotype was significant $[F(1,59)=4.87, P=0.031]$. 


\section{Discussion}

We found a quantitative association of AAL severity with MAOA. The involvement of MAOA in impulsive, aggressive or antisocial behavior is well established: The most extreme lack of MAOA, a null mutation, was reported in a large extended family with male members prone to aggressive, violent outbursts (Brunner, 1993). Creation of an MAOA "knock-out" mouse strain that is abnormally aggressive confirmed this phenotype in an animal model (Cases et al., 1995). Early-onset alcohol dependence with antisocial traits has consistently been reported to be associated with MAOA alleles that imply low MAO activity: MAOA (CA $)_{n^{\prime}}$ Parsian et al. (1995); MAOA (VNTR), Gade et al. (1998); MAOA (T1460C), Parsian (1999) and Parsian and Cloninger (2001); MAOA-LPR, Samochowiec et al. (1999). Gade et al. (1998) found one VNTR allele to be more frequent in substance-dependent patients (a group that may have AAL characteristics), compared with purely alcohol-dependent patients. However, in adolescent patients with early onset substance abuse, the longer repeat alleles (> 115) of MAOA $(\mathrm{CA})_{\mathrm{n}}{ }^{\prime}$ were nonsignificantly higher than for controls (Vanyukov et al., 1995). More recently, Samochowiec et al. (1999) reported that the low activity allele of a promoter variant, MAOA LPR, was more frequent in male alcoholics with antisocial personality disorder than in the control population. While the MAOA-LPR (Sabol et al., 1998) and the Fnu4HI alleles (Hotamisligil and Breakefield, 1991) have demonstrated functional differences, the others are presumed to show association with AAL due to linkage disequilibrium with Fnu4HI. The $\mathrm{C}$ allele was found associated with shorter-repeat $(C A)_{n} \leq 115$ alleles in the current study and by Parsian (1999).

There is converging evidence of association of low MAO activity with AAL, but only when studies employ alcoholism subtypes. We have found association of low activity alleles of MAOA with antisocial symptoms, a quantitative trait, but no evidence for preferential transmission of MAO alleles from the mother to proband in HRR (since it is X-chromosome linked, no MAO allele will be transmitted from the father to a male proband). Two points may explain this apparent discrepancy. First, quantitative ASSOC analysis of severity may in general be more sensitive. More importantly, the HRR analysis tests transmission based on diagnosis (AAL), and the sample tested here as probands may differ from those tested in case-control studies. The HRR design requires ascertainment of an affected proband and both parents, and is considered a very effective way to control internally for genetic admixture (Lander and Schork, 1994). However, participants with both living parents who are willing to volunteer for a lengthy assessment are only a small fraction of affected probands with antisocial personality disorder. This may have introduced a selection bias.

Another issue is that we did not adjust statistically for testing multiple polymorphisms. None of our results would be significant if a traditional Bonferroni correction were applied (i.e., nominal $\alpha$ of $0.05 / 17$ tests $=$ corrected $\alpha$ of 0.0029 ). However, such corrections are generally too conservative unless sample sizes are very large; rather, they increase the likelihood of falsely dismissing an important result (Rothman, 1990; Perneger, 1998). Where analyses are based on a priori hypotheses but power is limited, the latter danger is more critical. Our sample size provided sufficient power $(0.80)$ to show large effects (i.e., differences among group means of at least one half of a standard deviation), but only weak power to show smaller effects. Overall, our results as well as those in the literature are consistent with the idea that MAOA is associated with antisocial or impulsive features but not with alcoholism, broadly defined.

It is not clear how a putative MAO association with AAL would be reflected in serotonergic neurotransmission, given several complexities. First, previous research showing an association between alcoholism and platelet MAO activity may be confounded by another variable, smoking, because MAO activity may be inhibited by smoking (Whitfield et al., 2000). It is unclear whether the relationship between smoking and MAO has a genetic basis, but alcohol dependence is probably not independently related to platelet MAO (Whitfield et al., 2000). In our sample, as in most clinical samples, smoking and alcoholism are difficult to analyze separately; most of the probands were current or past smokers $(84 \%)$. However, the two MAOA markers we analyzed do not relate to platelet MAO activity; therefore, smoking may not confound the associations reported here. There are two forms of this enzyme, MAO-A and MAO-B; platelets express only MAO-B (Berry et al., 1994).

The second complexity arises because it is not clear how the consistent associations found between AAL and low MAO activity fit with theories and data suggesting that low serotonin function is linked to impulsivity and behavioral under control (reviewed in Hill et al., 1999). Serotonin is preferentially degraded by MAO-A (reviewed in Shih and Thompson, 1999). Low MAO-A is expected to result in higher, not lower levels of serotonin in synapses; indeed, the MAOA knock-out mouse has ninefold more serotonin in the brain (Cases 
et al., 1995). Dysregulation in one component could lead to adaptation or compensation by other parts of the system. To clarify the precise role of MAO in serotonergic neurotransmission at the neural level, future studies should simultaneously measure MAO activity, serotonin level and metabolites, behavioral symptomatology, and DNA markers.

Future studies should strive to examine joint and interactive effects of DNA markers. Ten allelic variants in the serotonin transporter promoter (Nakamura et al., 2000) and five in the MAOA area (see earlier) are already available. Interaction effects could obscure singlegene effects, and could cause some of the inconsistent findings among studies that examined only one marker. Interactions between markers are beginning to be investigated with other phenotypes and markers than those tested here; for example, GABA ${ }_{\mathrm{Aa}} \times$ HTTLPR effects on low response to alcohol (Schuckit et al., 1999), and HTR2C $\times$ DRD4 effects on personality scales (Ebstein et al., 1997; Kuhn et al., 1999). Large sample sizes will be required for testing complex effects of multiple genes. With methods now available to test association even in the presence of population stratification (Pritchard et al., 2000), population-based quantitative association tests may be better suited than family studies to provide the large sample sizes required.

\section{Acknowledgments}

This research was supported by NIAAA grants R21 AA10696, T32 AA07477, F32 AA0553, and K01 AA00295. Some of the results in this paper were obtained using the S.A.G.E. program package, which is supported by a US Public Health Service Resource Grant (1 P41 RR03655) from the National Center for Research Resources. The authors wish to thank the staff of the University of Michigan Addiction Research Center for assistance in conducting the study, and to thank Eric Slattery and Jennifer Edgar for technical assistance.

\section{References}

Ballenger JC, Goodwin FK, Major LF, Brown GL (1979). Alcohol and central serotonin metabolism in man. Arch Gen Psychiatry 36:224-227.

Berry MD, Juorio AV, Paterson IA (1994). The functional role of monoamine oxidases A and B in the mammalian central nervous system. Prog Neurobiol 42:375-391.

Black CGM, Chen Z-Y, Craig IW, Powell JF (1991). Dinucleotide repeat polymorphism at the MAOA locus. Nucl Acids Res 19:689.

Brunner HG, Nelen M, Breakefield XO, Ropers HH, van Oost BA (1993). Abnormal behavior associated with a point mu- tation in the structural gene for monoamine oxidase A. Science 262:578-580.

Cases O, Seif I, Grimsby J, Gaspar P, Chen K, Pournin S, et al. (1995). Aggressive behavior and altered amounts of brain serotonin and norepinephrine in mice lacking MAOA. Science 268:1763-1766.

Chen WJ, Loh EW, Hsu Y-PP, Chen C-C, Yu J-M, Cheng ATA (1996). Alcohol-metabolizing genes and alcoholism among Taiwanese Han men: independent effect of ADH2, ADH3, and ALDH2. Br J Psychiatry 168:762-767.

Cloninger CR (1987). Neurogenetic adaptive mechanisms in alcoholism. Science 236:410-416.

Cloninger C, Bohman M, Sigvardsson S (1981). Inheritance of alcohol abuse: cross fostering analysis of adopted men. Arch Gen Psychiatry 38:861-868.

Ebstein RP, Segman R, Benjamin J, Osher Y, Namanov L, Belmaker RH (1997). 5-HT2C (HTR2C) serotonin receptor gene polymorphism associated with the human personality trait of reward dependence: Interaction with dopamine D4 receptor (D4DR) and dopamine D3 receptor (D3DR) polymorphisms. Am J Med Genet (Neuropsychiatr Genet) 74:65-72.

Edenberg HJ, Reynolds J, Koller DL, Begleiter H, Bucholz KK, Conneally PM, et al. (1998). A familybased analysis of whether the functional promoter alleles of the serotonin transporter gene HTT affect the risk for alcohol dependence. Alcoholism Clin Exp Res 22:1080- 1085.

Erdmann J, Shimron-Abarbanell D, Rietschel M, Albus M, Maier W, Korner J, et al. (1996). Systematic screening for mutations in the human serotonin-2A (5- HT2A) receptor gene: identification of two naturally occurring receptor variants and association analysis in schizophrenia. Hum Genet 97:614-619.

Falk CT, Rubenstein P (1987). Haplotype relative risks: an easy reliable way to construct a proper control sample for risk calculations. Ann Hum Genet 51:227-233.

Foroud T, Edenberg HJ, Goate A, Rice J, Flury L, Koller DL, et al. (2000). Alcoholismsusceptibility loci: confirmation studies in a replicate sample and further mapping. Alcoholism Clin Exp Res 24:933-945.

Gade R, Muhleman D, Blake H, MacMurray J, Johnson P, Verde R, et al. (1998). Correlation of length of VNTR alleles at the X-linked MAOA gene and phenotypic effect in Tourette syndrome and drug abuse. Mol Psychiatry 3:50-60.

Gelernter J, Cubells JF, Kidd JR, Pakstis AJ, Kidd KK (1999). Population studies of polymorphisms of the serotonin transporter gene. Am J Med Genet 88:61-66.

George VT, Elston RC (1987). Testing the association between polymorphic markers and quantitative traits in pedigrees. Genet Epidemiol 4:193-201.

Hallikainen T, Saito T, Lachman HM, Volavka J, Pohjalainen T, Ryyna" nen O-P, et al. (1999). Association between low activity serotonin transporter promoter genotype and early onset alcoholismwith habitual impulsive violent behavior. Mol Psychiatry 4:385-388.

Hammoumi S, Payen A, Favre JD, Balmes JL, Benard JY, Hus- 
son M, et al. (1999). Does the short variant of the serotonin transporter linked polymorphic region constitute a marker of alcohol dependence?. Alcohol 17:107-112.

Hill EM, Stoltenberg SF, Burmeister M, Closser M, Zucker RA (1999). Potential associations among genetic markers in the serotonergic system and the antisocial alcoholismsubtype. Exp Clin Psychopharmacol 7:103- 121.

Himei A, Kono Y, Yoneda H, Sakai T, Koh J, Sakai J, et al. (2000). An association study between alcoholism and the serotonergic receptor genes. Alcoholism Clin Exp Res 24:341-342.

Hotamisligil GS, Breakefield XO (1991). Human monoamine oxidase A gene determines levels of enzyme activity. Am J Hum Genet 49:383-392.

Ishiguro H, Saito T, Akazwa S, Mitushio H, Tada K, Enomoto M, et al. (1999). Association between drinking-related antisocial behavior and a polymorphism in the serotonin transporter gene in a Japanese population. Alcoholism Clin Exp Res 23:1281-1284.

Kuhn KU, Meyer K, Nothen MM, Gansicke M, Papassotiropoulos A, Maier W (1999). Allelic variants of dopamine receptor D4 (DRD4) and serotonin receptor 5HT2C (HTR2C) and temperament factors: repliction tests. Am J Med Genet 88:168-172.

Lander ES, Schork NJ (1994). Genetic dissection of complex traits. Science 265:2037-2048.

Lappalainen J, Dean M, Charbonneau L, Virkkunen M, Linnoila M, Goldman D (1995a). Mapping of the serotonin 5-HT1D beta autoreceptor gene on chromosome 6 and direct analysis for sequence variants. Am J Med Genet 60:157-161.

Lappalainen J, Zhang L, Dean M, Oz M, Ozaki N, Yu DH, et al. (1995b). Identification, expression, and pharmacology of a Cys23-Ser23 substitution in the human 5-HT2c receptor gene (HTR2C). Genomics 27:274-279.

Lappalainen J, Long JC, Eggert M, Ozaki N, Robin RW, Brown GL, et al. (1998). Linkage of antisocial alcoholismto the serotonin 5-HT1B receptor gene in 2 populations. Arch Gen Psychiatry 55:989-994.

Lappalainen J, Long JC, Virkkunen M, Ozaki N, Goldman D, Linnoila M (1999). HTR2C Cys23Ser polymorphism in relation to csf monoamine metabolite concentrations ans DSM-III-R psychiatric diagnosis. Biol Psychiatry 46:821-826.

LeMarquand D, Pihl RO, Benkelfat C (1994). Serotonin and alcohol intake, abuse, and dependence: clinical evidence. Biol Psychiatry 36:326-337.

Lesch KP, Bengel D, Heils A, Sabol SZ, Greenberg BD, Petri $S$, et al. (1996). Association of anxiety-related traits with a polymorphism in the serotonin transporter gene regulatory region. Science 274:1527-1531.

Long JC, Knowler WC, Hanson RL, Robin RW, Urbanek M, Moore E, et al. (1998). Evidence for genetic linkage to alcohol dependence on chromosomes 4 and 11 from an autosome-wide scan in an American Indian population. Am J Med Genet (Neuropsychiatr Genet) 81:216-221.

McGue M (1994). Genes, environment, and the etiology of alcoholism. In: Zucker RA, Boyd G, Howard J, editors. The
Development of Alcohol Problems: Exploring the Biopsychosocial Matrix of Risk. Research Monograph No. 26, National Institute on Alcohol Abuse and Alcoholism. Rockville, MD: US Department of Health and Human Services.

McGuffin P, Owen MJ, O'Donovan MC, Thapar A, Gottesman II (1994). Seminars in Psychiatric Genetics. London: Royal College of Psychiatrists/Gaskell.

Nakamura M, Ueno S, Sano A, Tanabe H (2000). The human serotonin transporter gene linked polymorphism (5-HTTLPR) shows ten novel allelic variants. Mol Psychiatry 5:32-38.

New AS, Gelernter J, Yovell Y, Trestman RL, Nielsen DA, Silverman J, et al. (1998). Tryptophan hydroxylase genotype is associated with impulsive-aggression measures: a preliminary study. Am J Med Genet 81:13-17.

Nielsen DA, Goldman D, Virkkunen M, Tokola R, Rawlings R, Linnoila M (1994). Suicidality and 5- hydroxyindoleacetic acid concentration associated with a tryptophan hydroxylase polymorphism. Arch Gen Psychiatry 51:34-38.

Nielsen DA, Virkkunen M, Lappalainen J, Eggert M, Brown GL, Long JC, et al. (1998). A tryptophan hydroxylase gene marker for suicidality and alcoholism. Arch Gen Psychiatry 55:593-602.

Ogilvie AD, Battersby S, Bubb VJ, Fink G, Harmar AJ, Goodwim GM, Smith CA (1996). Polymorphism in serotonin transporter gene associated with susceptibility to major depression. Lancet 347:731-733.

Parsian A (1999). Sequence analysis of exon 8 of MAO-A gene in alcoholics with antisocial personality and normal controls. Genomics 55:290-295.

Parsian A, Cloninger CR (2001). Serotonergic pathway genes and subtypes of alcoholism: association studies. Psychiatr Genet 11:89-94.

Parsian A, Suarez BK, Tabakoff B, Hoffman L, Ovchinnikova L, Fisher L, Cloninger CR (1995). Monoamine oxidases and alcoholism: I. Studies in unrelated alcoholics and normal controls. Am J Med Genet (Neuropsychiatr Genet) 60:409-416.

Perneger TV (1998). What's wrong with Bonferroni adjustments?. Br Med J 316:1236-1238.

Pritchard JK, Stephens M, Rosenberg NA, Donnelly P (2000). Association mapping in structured populations. Am J Hum Genet 67:170-181.

Reich T, Cloninger CR (1990). Time-dependent model of the familial transmission of alcoholism. In: Cloninger CR, Begleiter $\mathrm{H}$, editors. Genetics and Biology of Alcoholism. Cold Springs Harbor, NY: Cold Springs Harbor Laboratory Press.

Reich T, Edenberg HJ, Goate A, Williams, Rice JP, van Eerdewegh P, et al. (1998). Genome-wide search for genes affecting the risk for alcohol dependence. Am J Med Genet (Neuropsychiatr Genet) 81:207-215.

Rice JP, Reich T, Bucholz KK, Neuman RJ, Fishman R, Rochberg N, et al. (1995). Comparison of direct interview and family history diagnoses of alcohol dependence. Alcoholism Clin Exp Res 19:1018-1023.

Robins LN, Helzer JE, Croughan J, Ratcliff KS (1981). National Institute of Mental Health Diagnostic Interview Schedule. Arch Gen Psychiatry 38:381-389. 
Rothman KJ (1990). No adjustments are needed for multiple comparisons. Epidemiology 1:43-50.

Rubenstein P, Walker M, Carpenter C, Carrier C, Krassner J, Falk C, Ginsberg F (1981). Genetics of HLA disease associations: the use of haplotype relative risk (HRR) and the 'haplo-delta' (Dh) estimates in juvenile diabetes fromracial groups [Abstract]. Hum Immun 3:384.

S.A.G.E. (1998) Statistical Analysis for Genetic Epidemiology, Release 3.1 [computer program]. Cleveland, $\mathrm{OH}$ : Department of Epidemiology and Biostatistics, Rammelkamp Center for Education and Research, Case Western Reserve University.

Sabol SZ, Hu S, Hamer D (1998). A functional polymorphism in the monoamine oxidase A gene promoter. Hum Genet 103:273-279.

Samochowiec J, Lesch KP, Rottman M, Smolka M, Syagailo YV, Okladnova O, et al. (1999). Association of a regulatory polymorphism in the promoter region of the monoamine oxidase A gene with antisocial alcoholism. Psychiatry Res 86:67-72.

Sander T, Harms H, Dufeu P, Kuhn S, Hoehe M, Lesch K-P, et al. (1998). Serotonin transporter gene variants in alcohol-dependent subjects with dissocial personality disorder. Biol Psychiatry 43:908-912.

Schuckit MA, Mazzanti C, Smith TL, Ahmed U, Radel M, Iwata N, Goldman D (1999). Selective genotyping for the role of 5-HT2A, 5-HT2C, and GABA $\alpha 6$ receptors and the serotonin transporter in the level of response to alcohol: a pilot study. Biol Psychiatry 45:647-651.

Sherif F, Hallman J, Oreland L (1992). Low platelet gammaaminobutyrate aminotransferase and monoamine oxidase activities in chronic alcoholic patients. Alcoholism Clin Exp Res 16:1014-1020.

Shih JC, Thompson RF (1999). Monoamine oxidase in neuropsychiatry and behavior. Am J Hum Genet 65:593-598.

Thomasson HR, Crabb DW, Edenberg HJ, Li T-K (1993). Alcohol and aldehyde dehydrogenase polymorphisms and alcoholism. Behav Genet 23:131-136.
Tabakoff B, Hoffman PL, Lee JM, Saito T, Willard B, De Leon-Jones F (1988). Differences in platelet enzyme activity between alcoholics and nonalcoholics. New Engl J Med 318:134-139.

Vanyukov MM, Moss HB, Yu LM, Tarter RE, Deka R (1995). Preliminary evidence for an association of a dinucleotide repeat polymorphism at the MAOA gene with early onset alcoholism/substance abuse. Am J Med Genet (Neuropsychiatr Genet) 60:122-126.

Virkkunen M, Linnoila M (1993). Brain serotonin, type II alcoholismand impulsive violence. J Studies Alcohol Suppl 11:163-169.

von Knorring A-L, Bohman M, von Knorring L, Oreland L (1985). Platelet MAO activity as a biological marker in subgroups of alcoholism. Acta Psychiatri Scand 72: 51-58.

Weir BS (1990). Genetic Data Analysis: methods for discrete population genetic data. Sunderland, MA: Sinauer.

Whitfield JB (1994). ADH and ALDH genotypes in relation to alcohol metabolic rate and sensitivity. Alcohol Alcoholism 29:(Suppl. 2):59-65.

Whitfield JB, Pang D, Bucholz KK, Madden PA, Heath AC, StathamDJ, Martin NG (2000). Monoamine oxidase: Associations with alcohol dependence, smoking and other measures of psychopathology. Psychol Med 30:443-454.

Zucker RA (1987). The four alcoholisms: a developmental account of the etiologic process. In: Rivers PC, editor. Nebraska Symposium on Motivation Vol. 34. Alcohol and Addictive Behaviors. Lincoln, NE: University of Nebraska Press. pp. 27-83.

Zucker RA, Noll RB, HamH, Fitzgerald HE, Sullivan LS (1994). Assessing Antisociality with the Antisocial Behavior: Checklist reliability and validity studies. East Lansing and Ann Arbor, MI: Michigan State University- University of Michigan Longitudinal Study.

Zucker RA, Ellis DA, Fitzgerald HE, BinghamR, Sanford KP (1996). Other evidence for at least two alcoholisms II: life course variation in antisociality and heterogeneity of alcoholic outcome. Dev Psychopathol 8:831-848. 